\title{
"Too much grammar will kill you!" Teaching Spanish as a foreign language in Norway: What teachers say about grammar teaching
}

Sigrunn Askland

University of Agder

\begin{abstract}
Exam results show that many Norwegian students lack communicative competence in their second foreign language. This study investigates Spanish language instruction in Norway, in particular Spanish teachers' opinions about grammar teaching, and why and how grammar is taught in lower and upper secondary school. Furthermore, the study explores whether common grammar teaching approaches are primarily explicit (rules provided) or implicit (rules not provided), inductive (language first) or deductive (rules first), and whether the language of instruction is primarily Norwegian or Spanish. The data comprise interviews with teachers and classroom observations, as well as teaching plans and other material. The analyses of the interviews and the observations show that the teachers think that grammar instruction is an important part of foreign language instruction, and they seem to prefer an explicit, deductive approach. The language of grammar instruction is predominantly Norwegian, independent of the teacher's native language. Based on the findings, I conclude that teachers may consider introducing more inductive approaches to grammar instruction, as well as providing students with more target language (TL) input and opportunities for communication in the TL.
\end{abstract}

\section{Keywords}

grammar teaching, foreign language acquisition, teacher cognition, Spanish, secondary school in Norway 


\section{Introduction}

Spanish is among the most widely spoken languages in the world by number of native speakers. It is by far the most commonly studied foreign language (FL) in the US (Modern Language Association, 2018), and it is the third most popular FL in Europe after English and French (Eurostat, 2017). In Norway, Spanish is at present the most popular FL (Fremmedspråksenteret, 2018). English is an obligatory subject from year one in primary school, whereas a second FL, such as Spanish, is optional from years 8-10 (level 1). In upper secondary school, students who have chosen the Programme for Specialisation in General Studies can continue to study the same FL (level 2), or they can start afresh with a new FL (level 1). A third option is to choose vocational studies, which does not require students to study a third language.

Whereas Norwegian students tend to achieve communicative competence in English, and their proficiency in English is among the highest in the world for non-native speakers (Education First, 2012), the situation is rather bleak for second FL acquisition. Exam results suggest that five years of FL instruction do not enable the majority of students to achieve communicative competence in the language they have chosen, with a high proportion of the students achieving below average grades on their written national exams in Spanish (Utdanningsdirektoratet, 2018b). Consequently, it is pertinent to ask why this is the case.

The foreign languages subject curriculum in the National Curriculum for Knowledge Promotion (LK06) (Utdanningsdirektoratet, 2006), states that the three main subject areas are 1) Language Learning, 2) Communication, and 3) Language, Culture and Society. The word grammar is not used explicitly in the Norwegian version of the subject curriculum. However, in the English version, students are supposed to use "basic linguistic structures and grammar to connect text" (level 1) and "use words, sentence structures and text connectors in a varied and appropriate way" (level 2). The wording in the curriculum makes it possible for teachers to implement a variety of approaches and teaching methods, as there are no explicit guidelines or recommendations. However, the subject curriculum guidance material (Utdanningsdirektoratet, 2015), states that "knowledge about the structures of a language is not a goal in itself, but a means to use the language actively" and "the teacher must adopt a practical approach to language teaching, i.e. create situations in which students can communicate in the language" (my translation). Furthermore, the following wording is 


\section{Nordic Journal of Modern Language Methodology}

included about the use of the target language (TL): "In order for students to be able to learn the language through usage, the teacher must act as a good role model and use the TL as much as possible" (my translation). Such an approach seems to correspond well with the tenets of communicative language teaching (CLT) (Simensen, 2007), and the methodological message of the Common European Framework (2018, p. 27). The guidelines of the written national exam (Utdanningsdirektoratet, 2018a) state that these exams "may test students' competence in all three main subject areas" (my translation), including the area communication and thus the ability to use "use words, sentence structures and text connectors in a varied and appropriate way". Hence, one may conclude that FL teachers should aim to implement a communicative approach to language teaching in which the TL is widely used, and in which focus on grammar also plays an important role.

Investigating teachers' opinions and practices regarding the role of grammar teaching, as well as the role of input in Spanish instruction, might help to gain increased insight into whether teachers' approaches correspond with the guidelines in the subject curriculum. In addition, by investigating these areas, some answers might be provided as to why many students in Norway achieve poor results and seem to lack communicative competence in their FL.

This brings us to the following research questions:

1. What are the teachers' opinions about the role of grammar teaching in Spanish as a foreign language (SFL) instruction? (What do teachers say?)

2. What approaches are used for teaching grammar in SFL instruction? (What do teachers do in the classroom?)

3. What is the favoured language of instruction for grammar teaching and other activities, Norwegian or Spanish?

\section{Literature review}

\section{Teacher cognition and the role of grammar in foreign language teaching}

Borg (2003) defines teacher cognition as "the unobservable cognitive dimensions of teaching -what teachers think, know, and believe and the relationships of these mental constructs to 
what teachers do in the language teaching classroom" (p. 81) ${ }^{1}$. In a study of teachers' beliefs, Phipps \& Borg (2009) found that teachers' thinking and behaviour are guided by a set of organized beliefs that are operated unconsciously. There is some evidence that teachers' beliefs and their classroom practices do not always coincide. Borg (2015) examined previous research on teacher cognition and grammar teaching. These findings suggest that teachers are influenced by their own language learning experiences as their main source of grammatical knowledge (p. 133). Furthermore, teachers think grammar should be taught at least sometimes but rarely refer to research or any particular methodology (p. 135).

Interestingly, a study of $\mathrm{FL}^{2}$ university students in the USA by Schulz (1996) shows a mismatch between what teachers think about students' perceptions of grammar, and what students say themselves: $76 \%$ of students say they like grammar, whereas only $30 \%$ of the teachers felt the students did. Moreover, a study by Berry (1997) suggests that teachers seem to overestimate the students' knowledge of grammatical terminology. A study from a Norwegian context (Hansejordet, 2009) seems to be in line with Berry (1997), and it is suggested that students often fail to understand the connection between grammatical knowledge and practical language use, and that they lack a meta-language that enables them to communicate about language. The teachers in Hansejordet's study expressed that they used far more traditional and teacher-centred methods than their ideals encouraged, which included more communicatively oriented and student-centred teaching. This discrepancy was ascribed to too many students in each class (about 30) and to lack of motivation among students. In another Norwegian study, Bugge and Dessingué (2009) found, perhaps surprisingly, that the implementation of LK06 had little influence on teachers' attitudes and practices. Llovet Vila (2016) interviewed and observed $8^{\text {th }}$ grade teachers of Spanish, and identified a gap between the intentions in the curriculum and how it was implemented in the classroom. Prior beliefs about language, teachers' own experiences from schooling, as well as their own teaching experiences, seemed to influence the extent to which they implemented the curriculum. Furthermore, teachers in Norway have also expressed that they need more didactic competence and formal education in Spanish (Bugge \& Dessingué, 2009; Hansejordet, 2009; Solfjeld, 2007). Analyses of grammar exercises in FL textbooks in German and French used

\footnotetext{
${ }^{1}$ Thus everything the teachers in the present study express (say, think etc.) about teaching is incorporated in the term 'teacher cognition'.

${ }^{2}$ German, Arabic, Chinese, French, Italian, Japanese, Russian and Spanish.
} 


\section{Nordic Journal of Modern Language Methodology}

in Norway showed preference for a clear deductive profile, which does not contribute significantly to promoting language awareness (Haukås, Malmqvist, \& Valfridsson, 2016; Vold, 2017). If this is also the case for textbooks in Spanish, it may result in a type of instruction that is primarily deductive and teacher-centred, as studies suggest that FL teachers' practices seem to be guided by textbooks (D. Brown, 2014; Solfjeld, 2007).

\section{Approaches to grammar teaching}

The role of grammar instruction in FL acquisition has been controversial, but has nevertheless maintained a central position both in research and in classroom materials and practice (Ur, 2011). Much research seems to support a positive role for grammar instruction in classroom settings. Although some research suggests good results for implicit instruction, i.e. grammar is not explained to the students (Ding, 2007; Williams, 2009), there is substantial evidence in favour of explicit instruction, i.e. grammar is explained, in classroom contexts (Leow, 2007; Norris \& Ortega, 2000; N. Spada \& Tomita, 2010; N. M. Spada, 1987). Perhaps more importantly, research seems to suggest that in a secondary school environment, any kind of grammar instruction is beneficial compared to no instruction (Tammenga-Helmantel, Arends, \& Canrinus, 2014).

However, different approaches can be used in grammar instruction, and the distinction has often been drawn between explicit and implicit instruction (Simensen, 2007, p. 50) and inductive and deductive approaches (Simensen, 2007, p. 214). The deductive-inductive dichotomy is concerned with sequencing (Glaser, 2014, p. 153), i.e., whether the rules are presented early in the lesson or whether the rules are discovered by the students or presented later in the lesson (see figure 1 below).

\begin{tabular}{|l|l|l|}
\hline \multicolumn{1}{|c|}{ Rules provided? } & $\begin{array}{l}\text { Explicit } \\
\text { (rules provided) }\end{array}$ & $\begin{array}{l}\text { Implicit } \\
\text { (no rules provided) }\end{array}$ \\
\hline $\begin{array}{l}\text { Deductive } \\
\text { (rules first) }\end{array}$ & Explicit-deductive & $\mathrm{n} / \mathrm{a}$ \\
\hline $\begin{array}{l}\text { Inductive } \\
\text { (language first) }\end{array}$ & Explicit-inductive & Implicit-inductive \\
\hline
\end{tabular}

Figure 1. Instructional combinations, grammar teaching. Adapted from DeKeyser (2003) and Glaser (2014)

Results from small-scale studies of the teaching of grammatical structures in French to college students indicate that grammatical accuracy is higher when an inductive approach is used (Haight, Herron, \& Cole, 2007; S. Vogel, Herron, Cole, \& York, 2011; S. P. Vogel \& 
Engelhard, 2011). A recent study focusing on qualitative self-report data and Irish L2 instruction for 11-12 year olds in Ireland shows similar results (Ní Dhiorbháin \& Ó Duibhir, 2017). Studies of Spanish as an FL also suggest positive results for an inductive approach both in a university context and in an upper secondary school context (Russell, 2014; Shaffer, 1989).

\section{Use of the target language in foreign language teaching}

Much research has shown that TL input is crucial for successful language acquisition (Crossley, Kyle, \& Salsbury, 2016; Krashen, 1985; Rothman \& Guijarro-Fuentes, 2010; Unsworth, 2008). There has been much discussion, including lively debates, about the use of the L1 in second/ foreign language teaching (Antón \& Dicamilla, 1999; Auerbach, 1993; Polio \& Duff, 1994; Wells, 1999), and whether a monolingual, bilingual or multilingual approach should be used (Cummins, 2007; Jessner, 1999). Ample research in the field of L1 use in FL acquisition exists (See Galindo (2016) for a list of references from different countries). Teachers' use of the TL has been shown to vary significantly (Duff \& Polio, 1990), and a study of university FL classroom language showed that FL teachers were not fully aware of their language use, with their own accounts often contradicting their observed classroom behaviour. A Swedish study by Stoltz (2011) reveals that the more the teachers use the TL, the more the students try to express themselves in the TL. Studies suggest that FLteachers in Norway may use the L1 more than is beneficial for the students (Brevik, forthcoming; Heimark, 2013; Vold, 2018), thus depriving students of opportunities for TL input and subsequent use.

To sum up, there is evidence to suggest that teachers' beliefs and their classroom practices do not always coincide. Furthermore, there might be a mismatch between teachers' and students' perceptions of grammar, and between the teachers' estimations of students' knowledge of grammatical terminology and the students' actual knowledge. Research suggests an overall positive role for grammar instruction in an FL setting, and inductive approaches may be more beneficial for students' learning outcomes than deductive approaches. In the Norwegian context, it is suggested that there is a gap between the intentions of the curriculum LK06 and how it is implemented in the classroom. In FL textbooks used in Norway, a deductive approach is favoured, which in turn may influence the teachers' choice of method. As for the use of the target language, research suggests that 


\section{Nordic Journal of Modern Language Methodology}

Norwegian FL teachers' TL use is limited. Few studies of teacher cognition and/ or grammar teaching in relation to Spanish FL instruction in a Norwegian context exist. The present study will thus contribute to expanding the body of knowledge in the field.

\section{Method}

\section{Research design}

To investigate teachers' opinions about the role of grammar teaching and their corresponding approaches and methods, a qualitative case-study approach was applied, using semi-structured interviews, observations and the collection of teaching plans and material. Such a triangulating technique may improve the validity of a qualitative study (Cohen, Manion, \& Morrison, 2011, p. 195). I interviewed 10 teachers of Spanish, five in lower secondary school and five in upper secondary school, and observed 30 lessons of Spanish teaching between January and November 2017. The project has been approved by the Data Protection Official for Research (NSD).

\section{Research tools and procedure}

The goal of the interviews was to investigate the teachers' opinions about grammar teaching, their approaches to grammar teaching and their attitudes to the use of the target language vs. the use of the L1. A semi-structured interview guide (Silverman, 2011, p. 162) was prepared and piloted before the interviews, and subsequently simplified by removing some of the keywords and questions that were not essential to answer the research questions. The teachers were asked for their opinions about grammar instruction and about what methods they used in the classroom. The questions were open-ended, and no particular definition of grammar was provided, i.e., it was up to each teacher to interpret and define the term "grammar teaching". Furthermore, the teachers were asked questions about tests, feedback and teaching material, their use of the target language and how they think students learn the most. All teachers except two (who were interviewed together for practical reasons) were interviewed individually. The interviews took place in a separate room $^{3}$ at the workplace of the informant in question. All the interviews were conducted in Norwegian, audio recorded, and subsequently transcribed and analysed using NVivo software. The quotes have been translated from Norwegian into English by the author.

\footnotetext{
${ }^{3}$ Except in one case where it was difficult to find a separate room, so the interview took place in the staff room.
} 


\section{Nordic Journal of Modern Language Methodology}

The purpose of the observations was to investigate whether the grammar teaching approaches were deductive or inductive and whether the instruction was implicit or explicit. Furthermore, I wanted to observe the extent to which the target language, Spanish, was used in the classroom. Finally, I wanted to find out whether what the teachers said they did coincided with what actually happened in the classroom.

Before the observations were carried out, an observation scheme was designed and piloted. During the pilot observations it became clear that the observation scheme was too elaborate, and it was simplified to include two main categories: 'what does the teacher do?' and 'what do the students do?' The observations in this study took place sometime after the interviews, typically two to four weeks afterwards ${ }^{4}$. Field notes taken during the observations included information about type of activity, methods used, time spent on each activity and use of the TL.

According to Klette ${ }^{5}$, observing three or four lessons gives a reasonably reliable picture of what goes on in a certain teacher's classroom. Even the observation of two lessons gives a relatively good impression of the teaching style of that teacher. I aimed to observe at least two lessons of teaching conducted by every teacher, but this was not always possible for practical reasons. The teachers decided when I could come and observe, and lessons by the same teacher were observed on the same day if their teaching involved different classes, or within a week or two if the teaching involved the same class ${ }^{6} . \mathrm{Most}^{7}$ of the participating teachers were observed while teaching between two and four 45 or 60 -minute lessons of Spanish. They were observed in ordinary classroom situations, and my presence as an observer was announced to the teachers and the students in advance. The classrooms were of the traditional type ${ }^{8}$, and the students were seated in rows. To interfere and intrude as little as possible in the actual teaching, and for practical, ethical and economic reasons, I decided not to videotape, take pictures or record during the observations. The observations can be defined

\footnotetext{
${ }^{4}$ In two cases the observations had to be postponed over the summer for practical reasons, and took place about five months after the interview.

${ }^{5}$ Observation course, Kirsti Klette, November 11, 2016 University of Oslo

${ }^{6}$ In Norwegian lower secondary schools, Spanish instruction usually consists of two or three 45-minute units, i.e., 90-135 minutes of instruction per week. In upper secondary school: 45-minute units, usually two consecutive units twice a week, i.e., 180 minutes of Spanish instruction every week.

${ }^{7}$ One teacher was observed for 45 minutes and another for 60 minutes only, as they were pressed for time.

${ }^{8}$ One exception: one of the rooms was originally a meeting room, and the students were seated around a big, oval table. According to the teacher, the students liked the arrangement.
} 
as semi-structured as there was an agenda of issues, and data were gathered to illuminate these issues (Cohen et al., 2011, p. 457). The position of the observer can be defined as the observer-as-participant: it was overt, usually detachted from the group, but occasionally participating in the groups' activities (Cohen et al., 2011, p. 457).

After the observations, the teachers were given a post-observation questionnaire to determine whether the students, as well as the teachers themselves, acted as they would normally do in a teaching situation. The purpose of the questionnaire was to check for possible observer effect, i.e. participants changing their behaviour because they are being observed (Cohen et al., 2011, p. 473; Labov, 1972).

\section{Sample}

The data material is collected from four different lower secondary schools and four upper secondary schools, which varied in size and study programmes offered. The schools are located in the southern part of Norway for proximity reasons. The participating teachers were recruited by contacting school adminstrations, as well as former colleagues and acquaintances, and asking them to suggest possible informants. Participants were thus recruited through a type of convenience sampling (Cohen et al., 2011, p. 155). However, the purpose of the selection of Spanish teachers was to ensure a certain variation in the sample with regard to educational background, experience and level of Spanish, so the sampling was also strategic to a certain degree. Ten teachers of Spanish were interviewed, five in lower secondary school (years 8-10) and five in upper secondary school (years 11-13). There were three male and seven female teachers in the sample, and they were all experienced teachers. Most interviews were conducted individually, and lasted for about an hour 9 .

Table 1 below presents the 10 informants in terms of education, teaching experience, time spent in a Spanish-speaking country and language proficiency. The informants are numbered from I 1 to I 13, and their real names are replaced by pseudonyms.

Table 1. Distribution of the informants across different variables

\begin{tabular}{lllll}
\hline $\begin{array}{l}\text { Informant } \\
\text { (teacher) }\end{array}$ & $\begin{array}{l}\text { Higher } \\
\text { education }\end{array}$ & $\begin{array}{l}\text { Teaching } \\
\text { experience } \\
\text {-years }\end{array}$ & $\begin{array}{l}\text { Time spent in } \\
\text { Spanish- }\end{array}$ & $\begin{array}{l}\text { Language } \\
\text { proficiency } \\
\text { (self-reported) }\end{array}$
\end{tabular}

\footnotetext{
${ }^{9}$ Exceptions: two teachers were interviewed together for practical reasons for $1 \mathrm{hr}, 35 \mathrm{~min}$; two teachers were interviewed for only about $35 \mathrm{mins}$, as they had other pressing matters to attend to.
} 


\begin{tabular}{lllll}
\hline & $\begin{array}{l}\text {-ECTS credits, } \\
\text { Spanish }\end{array}$ & $\begin{array}{l}\text { speaking } \\
\text { country }\end{array}$ & \\
I 1-Elise & 60 & $15-20$ & $>12$ months & B2 \\
\hline I 2-Felipa & 60 & $5-9$ & $>12$ months & $\mathrm{NS}^{10}$ \\
\hline I 3-Gerda & 30 & $10-14$ & $<3$ months & $\mathrm{B} 1$ \\
\hline I 5-Bruno & 60 & $5-9$ & $>12$ months & $\mathrm{NS}$ \\
\hline I 6-Dorte & 75 & $>20$ & $<3$ months & $\mathrm{A} 2$ \\
\hline I 7-Ada & 60 & $>20$ & $<3$ months & $\mathrm{B} 1$ \\
\hline I 8-Gloria & 150 & $15-20$ & $>12$ months & $\mathrm{NS}$ \\
\hline I 10-Carlos & 150 & $15-20$ & $>12$ months & $\mathrm{NS}$ \\
\hline I 12-Even & $\mathrm{MA}$ & $10-14$ & $3-6$ months & $\mathrm{C} 2$ \\
\hline I 13-Oda & 60 & $10-14$ & $>12$ months & $\mathrm{C} 2$
\end{tabular}

It is important to note that all teachers have the necessary qualifications needed to teach a foreign language in Norway ${ }^{11}$, and are experienced teachers of Spanish. All of them have taught for more than five years, and eight teachers have taught for at least ten years. Four of the informants are native speakers (NS) of Spanish. Of the remaining six informants, two rate their proficiency in Spanish as C2, three as B1 or B2 and one as A2 (cf. the Common European Framework (2001).

It is noteworthy that six out of 10 informants have spent more than 12 months in a Spanish-speaking area. It is also interesting to note that self-reported language proficiency in Spanish seems to coincide with length of residence in a Spanish-speaking country. Those who report the lowest levels of proficiency (I 3: B1, 6: A2, 7: B1) also report the shortest length of residence $(I 3,6,7)$. All the participating schools are located in the southern part of Norway, so there may be unofficial connections between some of the informants.

\section{Categorisation of the data}

The analysis can be defined as a deductive, thematic analysis. "A theme captures something important about the data in relation to the research question, and represents some level of patterned response or meaning within the data set" (Braun \& Clarke, 2006, p. 82). The coding process was carried out in NVivo, a software program for qualitative analysis.

The collected data were categorised into the following themes, based on the research questions: 1) Teacher cognition about grammar teaching and language learning, 2) approaches

\footnotetext{
${ }^{10} \mathrm{NS}=$ native speaker

${ }^{11}$ To teach years 8-10: at least 30 credits are required. To teach years 11-13: 60 credits are required
} 


\section{Nordic Journal of Modern Language Methodology}

used in grammar teaching, i.e. use of explicit or implicit instruction, use of deductive or inductive approaches, and 3) teacher cognition about use of the target language, i.e. what language(s) are used for grammar teaching, what language(s) are used in other teaching contexts?

\section{Reliability and validity}

The validity and reliability of this study need to be addressed as it includes a relatively small number of informants, in a limited geographical area. The use of interviews and observations might give rise to biases, and it is inevitable that the researcher will have some influence on the informants (Cohen et al., 2011, p. 204). Moreover, research interviews entail asymetrical power relations, and informants may choose to hold back information, which poses a threat to the reliability of the study (Kvale, Brinkmann, Anderssen, \& Rygge, 2015). The use of a semi-structured interview guide ensures some flexibility in that the informants are asked about the same research topics, but there is also room for the informants' reflections and spontaneous narratives. Changes in sequence and wording might be a threat to reliability. However, it might also be argued that flexibility enables the informants to demonstrate their unique way of looking at the world (Cohen et al., 2011, p. 205). The fact that the informants work at different schools and vary regarding educational background, work experience and gender, makes it possible to argue that they may be representative of Spanish teachers in the southern part of Norway.

As for the observations, possible threats to the validity might include that the informants are unrepresentative of the Spanish teacher population as a whole, and that the presence of an observer might bring about different behaviours, such as reactivity (Cohen et al., 2011, p. 210). To improve the validity of the observations, the teachers were asked to answer a post-observation questionnaire and answer each question $1-5^{12}$ by ticking off one of the following alternatives: agree - partly agree - partly disagree - disagree. The results leave one with the impression that my presence as an observer had little impact on the teachers' praxis. Eight teachers agreed that my presence as an observer had no impact on their teaching, and two teachers partly agreed that it had no impact. Questions 2 and 3 yielded similar results.

\footnotetext{
${ }^{12}$ Q1: Having an observer in the classroom had no impact on my teaching. Q2: Having an observer in the classroom made me nervous today. Q3: I acted as I usually do today. Q4: The class acted as they normally do today. Q5: This was a typical lesson in this class.
} 


\section{Nordic Journal of Modern Language Methodology}

Furthermore, it seems as if the students acted more or less as they would normally do (cf. questions 4 and 5). In the cases of 26 out of $28^{13}$ observed lessons, the teachers reported that they agreed that the class acted as they would normally. In the remaining lessons, the teachers partly agreed that the class acted as they would normally. One of the teachers said that this was because three of the most able students were absent. The other teacher did not give any reasons for their answer.

In response to question five, 19 of the lessons were regarded as typical in this class, six as partly typical and three as not typical. The reasons for reporting lessons as not typical were that one lesson included a test-situation, another one was students' first experience with learning stations, and finally one was a lesson where project work constituted most of the lesson. To conclude, it seems as if neither the teachers nor the students were much influenced by the presence of an observer.

\section{Limitations of the study}

As for the results of the observations, some caution is in order as I have only observed a very small number of all the lessons being taught by each teacher ${ }^{14}$. The results might have been different had it been possible to observe the teachers for several weeks or even months. Finally, the number of teachers is limited and they represent a limited geographical area. In other areas of Norway, opinions and practices among teachers may differ from those observed in the present study.

\section{Findings}

The findings are organised in accordance with the order of the three research questions.

Section a) deals with teachers' opinions about grammar teaching and section b) deals with the approaches that are used for grammar teaching as expressed by the teachers in the interviews. Section c) deals with the classroom observations of different approaches to grammar teaching and section d) concerns the use of the target language in the classroom and includes data from the interviews as well as the observations.

\footnotetext{
${ }^{13}$ One of the informants did not return the questionnaire. The total number of observed lessons is 30 .

${ }^{14}$ Number of Spanish lessons every year according to KL06: Years 8-10: $227 \mathrm{hrs}$, vg1: $113 \mathrm{hrs,}$, vg: $112 \mathrm{hrs,} \mathrm{vg}$ 3: $140 \mathrm{hrs}$ (60-minute units). https://www.udir.no/k106/FSP1-01/Hele/Timetall
} 


\section{a) What are the teacher's opinions about grammar teaching?}

In the interviews, the teachers were asked the following questions: What do you think about grammar teaching, and how important is it for the subject you teach?

The answers reveal that all the Spanish teachers in this study find it necessary and important to teach grammar explicitly. Many think that grammar is the foundation of a language, and for that reason it is important for students to learn the system of the language $(\mathrm{I} 1,2,3,7,8,12)$. Grammar is compared to for example a tool for language learning (Carlos I 10), traffic rules to make us feel safe (Gloria I 8) and the spine of a language (Gerda I 3), which underscores the importance they ascribe to grammatical knowledge. Furthermore, Bruno (I 5) thinks that some aspects of grammar are more important to learn than are others. He finds that being able to conjugate verbs, for example, is very important for communicative reasons, whereas for example the use of the indefinite article is less important when it comes to communication. Dorte (I 6) thinks that grammar teaching is important because students often ask questions about why they are to use a certain form of the verb in one situation but not in another. For example, why do we say "como" (I eat) when conjugating the verb "comer" (to eat), but "hago" (I do) instead of "haco" which would be the regular form of the verb "hacer" (to do)? She also sees it as a challenge to portion grammar teaching to ensure that the students are not overwhelmed, and consequently never teaches grammar for more than 20 minutes at a time. She adds that it is also important that the students are able to practice the new grammatical features immediately after the instruction so that they can see how they are used in context. Like Dorte, Oda (I 13) calls for caution, because she thinks it is possible to "kill students with grammar”. In her opinion, teachers should be careful to balance their methods and activities to ensure variation. Carlos (I 10) expresses similar views, by underscoring that grammar is only a tool that helps students develop an understanding of the language as a system, and that it should not be taught as a goal in itself.

Ada (I 7) thinks that gaining knowledge about the grammatical system is more important when students are learning a foreign language, than when they are working with their L1, because very few students have natural access to Spanish outside the classroom. Consequently, they need to have the grammatical structures explained to them by the teacher, to compensate for lack of input. In her opinion it is also important "to have a language to talk about language" - a metalanguage. 


\section{b) What approaches are used for teaching grammar?}

In the interviews it soon became clear that all the teachers teach grammar explicitly. In response to the question: "What is your approach to teaching grammar?" Five teachers say that they use the deductive approach the most (I 1, 2, 5, 7, 10). When introducing a new grammatical phenomenon, four teachers say that they always or usually use a deductive approach, i.e., they introduce and explain the grammatical rule (I 3, 6, 7, 12). The teachers give different explanations for preferring a deductive approach. Even (I 12) says that students, maybe surprisingly, seem to like rules:

They like to have the rules explained to them, and then practice using the rules in a context. Research may claim that this is not the way to do it, but the students often seem to prefer this method. I think the students like something concrete; they want a system, structure. When something does not fit into the structure, they may become frustrated.

Elise (I 1) says that she has tried inductive approaches, but she considers her attempts to have been rather unsuccessful. She recalls:

One time I was going to teach...don't remember (...), but I wrote long lists of verbs in that tense and asked the students if they were able to see a pattern. I think maybe two or three were able to do so! Maybe it would have been better, in the long run, to make them figure things out themselves, but because there is so little time you think that you don't have enough time to let them figure out the darn pattern! So that's why I write the rules and examples on the blackboard which the students copy and then work with tasks individually. I use the fast and efficient way more and more. I don't know if this is the best way to learn. Maybe the other one is better. But with the time that is available, it is better to explain to them how things are.

Ada (I 7) usually uses a deductive approach when introducing a new grammatical topic. Later the students and teacher may work together with examples, and then they work on their own. She likes repetition and tasks such as "fill in the blanks" and translations, which force the students to use for example a certain verb tense or structure. Afterwards, they go through the tasks in class. Ada continues: “And they repeat. It's a bit old-fashioned, but that's what I do. One can discuss what the best way of teaching a language is, but my experience is that this makes them feel more secure on the level they're at, especially in Spanish when they are at beginners' level".

Even if some of the teachers say that they prefer the deductive approach either for 


\section{Nordic Journal of Modern Language Methodology}

introducing a new topic or for grammar teaching in general, six of the teachers say that their practices vary between inductive and deductive approaches because they think that variation is important in language teaching (I 3, 6, 7, 8, 12, 13). Oda (I 13) says: "I think I should have used the inductive approach more, that we took the time..." Dorte (I 6) says that it is in a way her mantra to vary, so she uses both the inductive and the deductive approach. Sometimes she just introduces the topic they are going to work with, for example reflexive verbs, and then the students start working with it. As they go along, she picks out different elements whenever it is needed and explains in more detail. Gloria (I 8) also explains that she uses a multitude of methods and material. She may use poems and music. Sometimes she writes texts herself which contain specific grammar points or challenges, tells the students to read the texts and then asks them to look for topics they have talked about which concern grammar. Sometimes she writes texts that contain the students' mistakes and asks them to find the mistakes and correct them. Sometimes the students try to figure out the grammatical rules themselves, often in groups. She may hand out a text and ask the students to find, for example, the adjectives and work out a rule based on what they find in the text. According to Gloria, the students report that they learn a lot by working this way in groups. They say that it is easier to ask questions in a small group when not everybody in the class is listening to what they are saying. Bruno (I 5) thinks that playing games is an important part of learning. He has developed games for learning, e.g. how to conjugate verbs: "The use of games makes the students forget that they are learning something because they are playing. I like it when the students are having some fun”. Gerda (I 3) also mentions games, which she uses to create some variation for the students.

\section{c) Classroom observations of approaches to grammar teaching}

As illustrated in the table below, observations reveal that deductive approaches seem to dominate grammar teaching in both lower and upper secondary school. Furthermore, teacherfronted instruction, where the teacher spends a considerable amount of time asking the students questions in class, also seems to be a very common practice. Teachers might also use a combination of deductive grammar instruction and asking questions to make sure the students have understood the points that have been made. All the teachers use grammatical terminology 


\section{Nordic Journal of Modern Language Methodology}

when explaining grammatical rules, which requires that students are familiar with these terms if they are to benefit fully from the instruction.

Table 2. Teachers' observed practices, grammar teaching parts of the lessons.

\begin{tabular}{|c|c|c|}
\hline Teacher & $\begin{array}{l}\text { Metalanguage (grammatical terminology) } \\
\text { used during lessons }{ }^{15}\end{array}$ & Approach, grammar instruction \\
\hline I 1-Elise & Infinitive, verb, conditional tense & $\begin{array}{l}\text { Inductive: Focuses on student-centred pair work: } \\
\text { expressing opinions using the conditional tense, } \\
\text { translating sentences in future tense from } \\
\text { Norwegian into Spanish }\end{array}$ \\
\hline $\begin{array}{l}\text { I 2- } \\
\text { Felipa }\end{array}$ & $\begin{array}{l}\text { Infinitive, verb, pronouns, articles, definite/ } \\
\text { indefinite }\end{array}$ & $\begin{array}{l}\text { Deductive teaching - explains the rules. Verbs, } \\
\text { endings. } \\
\text { Students translate sentences from Spanish to } \\
\text { Norwegian (focus on verb endings, present tense). } \\
\text { Asks students to focus on pronunciation of certain } \\
\text { words }\end{array}$ \\
\hline $\begin{array}{l}\text { I } 3- \\
\text { Gerda }\end{array}$ & Article, verb, noun, adjective & $\begin{array}{l}\text { Deductive, teacher-centred. Explains grammatical } \\
\text { concepts. Provides examples of possible } \\
\text { sentences on blackboard }\end{array}$ \\
\hline $\begin{array}{l}\text { I 5- } \\
\text { Bruno }\end{array}$ & Verb, present tense & $\begin{array}{l}\text { Inductive: Student-centred, uses a game to } \\
\text { acquire verb-endings }\end{array}$ \\
\hline I 6-Dorte & -ar verb, present tense & $\begin{array}{l}\text { Deductive, teacher-centred: goes through rules, } \\
\text { how verbs are conjugated. } \\
\text { Student-centred: uses a puzzle to acquire verb } \\
\text { endings. } \\
\text { Asks students to focus on pronunciation of } \\
\text { certain words }\end{array}$ \\
\hline I 7-Ada & $\begin{array}{l}\text { Demonstrative pronouns, gender (masculine, } \\
\text { feminine), verb, infinitive marker, regular } \\
\text { verbs, 1. person, 2. person etc. }\end{array}$ & $\begin{array}{l}\text { Teacher-centred: Deductive teaching of the } \\
\text { present perfect. } \\
\text { Student-centred: students explain to each other } \\
\text { how to express the present perfect. Combine } \\
\text { words \& expressions and make sentences in past } \\
\text { tense }\end{array}$ \\
\hline $\begin{array}{l}\text { I 8- } \\
\text { Gloria }\end{array}$ & $\begin{array}{l}\text { Past tense, indefinido, imperfecto, irregular } \\
\text { verbs }\end{array}$ & $\begin{array}{l}\text { Teacher-centred: Deductive teaching of the past } \\
\text { tense. Asks students questions to check } \\
\text { understanding. } \\
\text { Teacher reads story. Stops when she gets to a } \\
\text { verb in the past tense, and asks whether students } \\
\text { would use imperfecto or indefinido. } \\
\text { Students write individual stories about when they } \\
\text { were children, using past tense. }\end{array}$ \\
\hline $\begin{array}{l}\text { I } 10- \\
\text { Carlos }\end{array}$ & $\begin{array}{l}\text { Present progressive, -ar verb, adverb, present } \\
\text { tense, irregular, regular, infinitive, gender, } \\
\text { forms of the definite article, indefinido, } \\
\text { futurum, stem-changing verbs, -er verb, hiato }\end{array}$ & $\begin{array}{l}\text { Deductive, explains rules - how the gerund is } \\
\text { constructed. } \\
\text { Students detect gerund in a text. } \\
\text { Asks students to describe pictures using the } \\
\text { gerund. } \\
\text { Asks students to focus on pronunciation of } \\
\text { certain words }\end{array}$ \\
\hline $\begin{array}{l}\text { I 12- } \\
\text { Even }\end{array}$ & Indefinido, imperfecto & $\begin{array}{l}\text { Deductive, explains rules - indefinido/ } \\
\text { imperfecto, } \\
\text { Fill inn tasks }\end{array}$ \\
\hline
\end{tabular}

\footnotetext{
15 Terminology was used in Norwegian, except the terms imperfecto and indefinido.
} 


\begin{tabular}{|l|l|l|}
\hline I 13-Oda & Reflexive verb, infinitive & $\begin{array}{l}\text { Partly deductive, partly inductive: Has a } \\
\text { conversation with the class about reflexive verbs } \\
\text { - asks students questions, answers some of them } \\
\text { herself. Writes rules on blackboard. } \\
\end{array}$ \\
& $\begin{array}{l}\text { Inductive: } \text { Student-centred activity: pair work } \\
\text { where they ask each other what their names are. }\end{array}$ \\
& \\
\hline
\end{tabular}

\section{d) How are the target language and the native language used in the classroom?}

As for language choice when teaching grammar, all the informants report in the interviews that they speak only Norwegian or mostly Norwegian when teaching grammar, and there seems to be a consensus that Spanish grammar should be taught in Norwegian or in a mixture of Norwegian and Spanish. Ada (I 7) says: "My goal is to speak as much Spanish as possible when we talk about a text, what we are going to do, ask the students as much as possible. When it's not about teaching grammar, I'll try to speak as much Spanish as possible. But I probably speak at least $40 \%$ Norwegian, because there is a lot of grammar”. Even (I 12) says that he uses both Norwegian and Spanish, but mostly Norwegian, when introducing a new grammatical topic, at least at the lower levels. But he also says:

I use Spanish more and more. For example today a student asked what "piso" (apartment) means. Then I can say: "piso significa apartamento". I try to explain the words, e.g., "barrio" (neighbourhood): es una parte de una ciudad. I use Spanish to explain what things mean. I do that more now.

All teachers say that they use more Spanish as the students become more proficient, but they say that even if their goal is to use as much Spanish as possible, they think they use too much Norwegian, including the teachers who are native speakers of Spanish. The reasons for speaking little Spanish vary. Some teachers want to make sure everybody understands what is being said, and they want to prevent loss of motivation among students (I 2, 7, 8, 13). Oda (I 13), who is a highly proficient speaker of Spanish, tries to explain why she speaks little Spanish:

I'm afraid that they'll lose their motivation. Not understand. Recently, there was a survey about learning gains at our school, and one student reported that she perceived that I thought they understood more than they actually did. She said: "Oda gets so disappointed if we don't understand". They feel that it is difficult, yes. 


\section{Nordic Journal of Modern Language Methodology}

Carlos (I 10) has had similar experiences: "I have met resistance at upper secondary school. The students were used to a teacher who explained and translated everything. I started to speak relatively simple Spanish, and the students reacted, they didn't want it, they complained to the principal. Why?"

Two teachers who report having relatively low levels of proficiency in Spanish, Gerda (I 3) and Ada (I 7), also mention that they feel insecure when they speak Spanish, and they wish that they could get feedback on their oral proficiency or have the opportunity to spend some time abroad. However, most of the teachers in this study are highly proficient in Spanish, thus limited use of the TL cannot be explained by teachers' inadequate language skills.

During the interviews, the teachers reported that they speak Norwegian or mostly Norwegian when teaching grammar, but that they aim to speak as much Spanish as possible in teaching contexts that do not involve explicit grammar teaching. The observations revealed that the teachers' assumptions seemed to be only partly correct. With the exception of Even (I 12), who speaks Spanish almost the entire time independent of topic or type of activity, the other teachers speak Norwegian most of the time when teaching grammar (as they said they did), but also when giving instructions, asking questions or disciplining students. The teachers who do attempt to give instructions and ask questions in Spanish, show a clear preference for translating these instructions and questions into Norwegian, or providing further, more detailed information in Norwegian: "Vamos a empezar con una prueba" (vi skal begynne med ei prøve/ let's start with a test) (Elise I 1). "Escribe en tu cuaderno" (skriv i skriveboka/ write in your notebook) (Dorte I 6). The most extreme case is Dorte (I 6) who utters just two words in Spanish during one of her lessons, namely: "buenos días" (good morning). All the teachers have in common that they greet the students in Spanish. My cautious claim is that the teachers in this study speak much more Norwegian than they think they do.

The table below gives an overview of classroom activities as observed by the researcher and the use of the L1 and the TL. As we can see, the teachers use mainly the L1 for grammar instruction, information about tests, content of the lesson and summing up the lessons. Most of the teachers who use a fair amount of the TL for lecturing and class discussions, provide translations of the TL words and sentences they just used. Only Even (I 12) uses the TL extensively and in most contexts. 
Table 3. Overview of teachers' use of $L 1$ and TL in different situations/ activities

\begin{tabular}{|c|c|c|}
\hline Type of activity in the classroom & Use of L1 by the informants & Use of TL by the informants \\
\hline Greetings & & All \\
\hline $\begin{array}{l}\text { Information about the content of } \\
\text { the lesson }\end{array}$ & $\begin{array}{l}\text { Elise (I 1), Bruno (I 5), Dorte (I 6), } \\
\text { Ada (I 7), Gloria (I 8), Oda (I 13) }\end{array}$ & $\begin{array}{l}\text { Elise (I 1)*16, Dorte (I 6), }{ }^{*} \text { Ada (I } \\
7 \text { ), }\end{array}$ \\
\hline Grammar teaching & $\begin{array}{l}\text { Elise (I 1), Felipa (I 2), Gerda (I } \\
\text { 3), Ada (I 7), Gloria (I 8), Carlos } \\
\text { (I 10), Oda (I 13) }\end{array}$ & Even (I 12) \\
\hline Information/ talking about tests & $\begin{array}{l}\text { Felipa (I 2), Gerda (I 3), Dorte (I } \\
\text { 6), Carlos (I 10), Oda (I 13) }\end{array}$ & Carlos (I 10) \\
\hline Explaining rules (games) & Bruno (I 5) & \\
\hline $\begin{array}{l}\text { Talking to students one-to-one } \\
\text { about how to solve exercises }\end{array}$ & Even (I 12) & Even (I 12) \\
\hline $\begin{array}{l}\text { Lecturing, class discussions about } \\
\text { subject matter }\end{array}$ & $\begin{array}{l}\text { Elise (I 1), Felipa (I 2), Gerda (I } \\
\text { 3), Bruno (I 5) Dorte (I 6), Ada (I } \\
\text { 7), Gloria (I 8), Carlos (I 10), Oda } \\
\text { (I 13) }\end{array}$ & $\begin{array}{l}\text { Elise (I 1)*, Felipa (I 2)*, Gerda (I } \\
\text { 3), Dorte (I 6)* } \\
\text { Ada (I 7)*, Gloria (I 8)*, Carlos (I } \\
\text { 10), } \\
\text { Even (I 12) }\end{array}$ \\
\hline $\begin{array}{l}\text { Introducing new vocabulary items } \\
\text { in Spanish }{ }^{17}\end{array}$ & & $\begin{array}{l}\text { Felipa (I 2), Dorte (I 6), Carlos (I } \\
\text { 10), Oda (I 13) }\end{array}$ \\
\hline $\begin{array}{l}\text { Focus on pronunciation of certain } \\
\text { sounds/ words }{ }^{18}\end{array}$ & & $\begin{array}{l}\text { Felipa (I 2), Dorte (I 6), Carlos (I } \\
\text { 10), Oda (I 13) }\end{array}$ \\
\hline Reading song lyrics, singing & & Carlos (I 10), Oda (I 13) \\
\hline Disciplining students & $\begin{array}{l}\text { Felipa (I 2), Gerda (I 3), Dorte (I } \\
\text { 6), }\end{array}$ & Carlos (I 10) \\
\hline Praising students & Gerda (I 3), Oda (I 13) & \\
\hline Summing up the lesson & $\begin{array}{l}\text { Gerda (I 3), Dorte (I 6), Gloria (I } \\
\text { 8), Oda (I 13) }\end{array}$ & \\
\hline
\end{tabular}

Oda (I 13) also makes use some of the students' previous knowledge of German and French when explaining the conjugation paradigm of ser (to be in Spanish) by asking them to help her compare and contrast the four languages Spanish, English, German and French.

The focus of this study is on the teachers, but it is important to note that the students in the classes I observed spoke very little Spanish. Their use of oral Spanish in an ordinary lesson was more or less restricted to the use of greetings, single vocabulary items, some reading aloud or in pairs, and occasionally a sing-along-song. Exceptions were Gerda and Even $(I 3,12)$ who included a fair amount of pair work where the students were instructed to speak Spanish.

\footnotetext{
16 Teachers marked with an asterisk (*) translate most of their Spanish sentences/ expressions into Norwegian.

${ }^{17}$ Only the new vocabulary item itself is expressed in Spanish, not further explanations/ contexts for use.

${ }^{18}$ Only the word itself is pronounced in Spanish, not further explanations or context.
} 


\section{Discussion and implications for teaching}

\section{Teacher cognition and approaches to grammar teaching}

Basturkmen (2012) finds, in her review study of the correspondence between teacher's practices and beliefs, that this correspondence is limited, and that teachers reported that external factors made it difficult for them to put their beliefs into practice. In the present study, however, teachers seem to do what they say they do with regard to approaches to grammar teaching. According to some of my informants (I 3, 5, 7, 8, 10, 13), great variation in student performances, as well as lack of motivation among students is a challenge in many FL classes. They ascribe this lack of motivation, among other things, to large class sizes, which in turn makes it difficult to adapt the instruction and necessary amount of feedback to the individual student's needs.

Studies of students' beliefs showed that students thought they could become fluent in another language in two years or less, and $60 \%$ of the Spanish and German students thought learning a new language was mostly about translating from their L1 (A. V. Brown, 2009). Mismatches between teachers' and students' expectations regarding language teaching can negatively affect the students' satisfaction with the language class (Horwitz, 1990; Kern, 1995; Schulz, 1996), and should therefore be addressed. Teachers should make an attempt to discuss different teaching approaches and learning outcomes with the students to help them develop autonomy and metacognitive knowledge, which is also in accordance with the aims of the subject curriculum. The latter point is briefly mentioned by Dorte (I 6) and Gloria (I 8), but it does not seem to be something that the majority of my informants are preoccupied with - at least they did not mention it. Oda (I 13), however, uses the students' previous knowledge of other languages when introducing grammar. According to Haukås (2014), multilingualism can be a resource for students if they are made aware of their existing knowledge and how this knowledge can be useful when acquiring a new language. Haukås claims that if students are to benefit fully from metacognition, it should be incorporated in all the schools's language subjects (p. 7).

Although most of the teachers in this study claim that variation between deductive and inductive approaches is important, they seem to prefer the deductive teaching approach when 
teaching grammar, and in particular when introducing new grammatical structures ${ }^{19}$. The teachers in Hansejordet's (2009) study referred to earlier also seemed to favour traditional and teacher-centred teaching methods, even if they would ideally have done something else. This is in line with the reflections of some of the teachers in the present study, who express that they are not certain that the "traditional" or deductive approach is the best, but they use it for pragmatic reasons. Elise (I 1) reports having tried the inductive approach, but says that these attempts were unsuccessful because they took too much time and the students were frustrated - particularly the less able students. This last point is interesting in the light of the study by Shaffer (1989), in which there is a claim that the inductive approach is better for these students as well, contrary to what some teachers seem to believe. Interestingly, studies have demonstrated that students seem to prefer the approach they are used to, i.e., the deductive, (A. V. Brown, 2009), even if another approach, the inductive, turns out to be more successful regarding learning gains (S. Vogel et al., 2011). The point that students seem to prefer the deductive approach is also mentioned by some of the informants in the present study (I 7, 9, 12). Consequently, students might be frustrated by new approaches to teaching, and trying something new in a class of students will often be time-consuming, and require extra efforts on the part of the teachers. However, as many students already achieve poor results in Spanish and seem to lack motivation, implementing more student-centred teaching approaches, including inductive approaches and tasks intended to promote language awareness, may lead to increased motivation and grammatical awareness and improved ability to use the TL.

The fact that the majority of Norwegian teenagers in the $8^{\text {th }}$ grade study an FL, and that an increasing number of students attend the general study programme in upper secondary school (Utdanningsforbundet, 2017), implies great variation among students regarding, for example, language aptitude, motivation, and peer involvement. As much as this might cause a challenge for the teachers, it is nevertheless the reality and needs to be adressed. On a more positive note, Spanish students seem to be highly motivated when they start in $8^{\text {th }}$ grade (Lindemann, 2008). However, these students are notably more disappointed with the subject than the French and German students, and many are dissatisfied with the teaching methods of their teachers (Carrai, 2014). My findings suggest that Spanish instruction in secondary

\footnotetext{
${ }^{19}$ Some teachers were familiar with the terms inductive and deductive; others were not. Based on their explanations of grammar teaching, it was still relatively easy to identify which approach they referred to.
} 


\section{Nordic Journal of Modern Language Methodology}

school comprises much teacher-centred instruction, often paired with deductive approaches to grammar teaching and little use of the target language. Such an approach to FL teaching may contribute to lack of motivation among students, because they do not feel that they develop communicative competence in the language, and finally may result in poor exam results. Furthermore, it is not in line with the intentions in the subject curriculum.

\section{Use of the target language}

Previous research (Levine, 2003) suggests that the teachers should provide more input to the students, for example by using the TL more. As for the use of the TL in the present study, the teachers seemed to think that they used it in more classroom situations than turned out to be the case. This is in line with previous research (Polio \& Duff, 1994) and shows that it is very difficult for teachers to assess to what degree they use the TL. Interestingly, observations revealed that the teachers who used a fair amount of Spanish in their lessons also provided the students with simultaneous translations of their Spanish words and sentences. Consequently, one might ask the following: why should the students bother to pay attention to what was being said in Spanish when they were given the Norwegian translation immediately after? I did not have the opportunity to ask the students about their perceptions of this, but it is an interesting area for further research. Furthermore, students should be encouraged to and given the opportunity to use the TL more in class (Tsou, 2005). The provision of input in language classes is important, but in addition, input probably also needs to be noticed and subsequently used by the students in communication for it to become a part of the students' speech (Swain, 2005). The observations in this study reveal that the students speak very little Spanish in class. I would, therefore, recommend increased implementation of activities that enable and encourage the students to use the TL. Studies show that peer activities, for example, are more likely to yield high rates of student language production than teacher-led instruction (Chavez, 2016). Moreover, if the teachers use the TL frequently in class, it will feel more natural for the students to do the same (Stoltz, 2011).

\section{Using the L1 vs. the TL in grammar teaching}

An interesting area of discussion that relates both to grammar teaching and to the use of the TL is whether grammar always needs to be taught in the students' L1. Much research suggests an important role also for the use of the L1 in FLA (Cook, 2001; Swain \& Lapkin, 2000). 


\section{Nordic Journal of Modern Language Methodology}

Their research, however, does not support excessive use of the L1, but optimal use. The L1 may serve as cognitive tool "whenever it is too difficult or time-consuming for the students to process and understand the TL (Cook, 2001, p. 418). Tsagari \& Diakou (2015) found that teachers' L1 use was influenced by the students' proficiency and needs. As mentioned previously, there seems to be a consensus among teachers in this study that grammar should be taught in the L1, as grammar is perceived as a difficult topic and teachers are afraid students will misunderstand and lose motivation if the TL is used. I would argue, however, that if teachers used the TL more when teaching grammar, this would lead to increased exposure to the TL for the students, as I do think there is room for more meaningful TL use also in the context of grammar instruction. In a study of TL use in the subject English in lower secondary school, it is suggested that teachers may be doing students a disservice by using the L1 for long stretches of time when teaching grammar, giving task instructions and providing practical information (Brevik, forthcoming), as findings suggest that students may not need the L1 to ensure comprehension. It might be appropriate to address this issue with regard to FL/ Spanish instruction as well. I also think that implementing an increased number of inductive approaches and fewer teacher-centred approaches to grammar teaching, would provide students with more opportunities to use the TL in class.

\section{Conclusion}

The findings of the present study suggest that teachers of Spanish as a foreign language find it important and necessary to teach grammar. Most of the teachers say that they think it is important to use an inductive as well as a deductive approach when teaching grammar. They favour Norwegian as the language of grammar instruction, but claim that they try to use as much Spanish as possible in other teaching contexts. Observations reveal that, in practice, the teachers seem to prefer the deductive approach when teaching grammar, and the language of instruction is primarily Norwegian, not only for grammar instruction but in most contexts. In those instances where Spanish is used as a medium of instruction, most teachers tend to translate the Spanish words and expressions into Norwegian.

Research in general and this article in particular advocate the use of more inductive approaches to grammar teaching, as well as providing more TL input to students by using Spanish as the primary medium of instruction. Furthermore, teachers should also provide the students with ample opportunities for speaking Spanish in class, in accordance with the 
intentions in the curriculum LK06. Some teachers report that they feel insecure about speaking Spanish. Others report that too many students in a class make it difficult to adapt the teaching methods to the students' needs. School administrations should, therefore, make it possible for these teachers to attend relevant courses, preferably in Spanish-speaking settings. In addition, attempts should be made to reduce the size of foreign language classes.

The focus of this study has been on the teachers and their practice, and more research is needed on FL teaching in a Norwegian setting. Areas for further research may include how different methodological approaches to FL instruction may influence subsequent learning gains and results among the students (e.g. deductive versus inductive approaches to grammar teaching), how the TL is used by teachers and students, and whether increased TL input leads to improved communicative competence and grammatical accuracy among students.

\section{References}

Antón, M., \& Dicamilla, F. J. (1999). Socio-Cognitive Functions of L1 Collaborative Interaction in the L2 Classroom. The Modern Language Journal, 83(2), 233-247. doi:doi:10.1111/0026-7902.00018

Auerbach, E. R. (1993). Reexamining English Only in the ESL Classroom. TESOL Quarterly, 27(1), 9-32. doi:10.2307/3586949

Basturkmen, H. (2012). Review of research into the correspondence between language teachers' stated beliefs and practices. System, 40(2), 282-295.

Berry, R. (1997). Teachers' awareness of learners' knowledge: The case of metalinguistic terminology. Language Awareness, 6(2-3), 136-146. doi:10.1080/09658416.1997.9959923

Borg, S. (2003). Teacher cognition in language teaching: A review of research on what language teachers think, know, believe, and do. 81-109. ISSN 1475-3049.

Borg, S. (2015). Teacher Cognition and Language Education: Research and Practice. London: Bloomsbury Publishing.

Braun, V., \& Clarke, V. (2006). Using thematic analysis in psychology. Qualitative Research in Psychology, 3(2), 77-101. doi:10.1191/1478088706qp063oa

Brevik, L. M. R., U. (forthcoming). Language use in L2 instruction: Monolingual, bilingual, or multilingual classrooms?

Brown, A. V. (2009). Students' and Teachers' Perceptions of Effective Foreign Language Teaching: A Comparison of Ideals. Modern Language Journal, 93(1), 46-60. doi:10.1111/j.1540-4781.2009.00827.x

Brown, D. (2014). The power and authority of materials in the classroom ecology. The Modern Language Journal, 98(2), 658-661.

Bugge, H. E., \& Dessingué, A. (2009). Rapport om «Språklæreres holdninger etter KL06». Forskergruppe for fremmed-og andrespråksopplaring (FFAO). Stavanger: Universitetet $i$ Stavanger, 1(4), 25. 
Carrai, D. (2014). Fremmedspråk på ungdomstrinnet. En analyse av motivasjon og andre faktorer involvert i elevenes fagvalg og tilfredshet med faget. Retrieved from http://urn.nb.no/URN:NBN:no-46001

Chavez, M. (2016). The first language in the foreign language classroom: teacher model and student language use - an exploratory study. Classroom Discourse, 7(2), 131-163. doi:10.1080/19463014.2016.1149499

Cohen, L., Manion, L., \& Morrison, K. (2011). Research methods in education. London: Routledge.

Cook, V. (2001). Using the first language in the classroom. Canadian modern language review, 57(3), 402-423.

Council of Europe. (2001). Common European Framework of Reference for Languages: learning, teaching, assessment. Retrieved from https://rm.coe.int/1680459f97

Council of Europe. (2018). Common European Framework of reference for languages: learning, teaching and assessment. Companion volume with new descriptors. Retrieved from https://rm.coe.int/cefr-companion-volume-with-new-descriptors2018/1680787989

Crossley, S., Kyle, K., \& Salsbury, T. (2016). A Usage-Based Investigation of L2 Lexical Acquisition: The Role of Input and Output. Modern Language Journal, 100(3), 702715. doi:10.1111/modl.12344

Cummins, J. (2007). Rethinking monolingual instructional strategies in multilingual classrooms. Canadian Journal of Applied Linguistics/Revue canadienne de linguistique appliquée, 10(2), 221-240.

DeKeyser, R. (2003). Implicit and explicit learning. In C. Doughty \& M. Long (Eds.), The handbook of second language acquisition (Vol. 14). Malden, Mass: Blackwell.

Ding, Y. (2007). Text Memorization and Imitation: The Practices of Successful Chinese Learners of English. System: An International Journal of Educational Technology and Applied Linguistics, 35(2), 271-280. doi:10.1016/j.system.2006.12.005

Duff, P. A., \& Polio, C. G. (1990). How Much Foreign Language Is There in the Foreign Language Classroom? Modern Language Journal, 74(2), 154-166. doi:10.1111/j.1540-4781.1990.tb02561.x

Education First. (2012). EF English Proficiency Index (EF EPI). Retrieved from https://www.ef.no/epi/

Eurostat. (2017). Foreign language learning statistics. Retrieved from http://ec.europa.eu/eurostat/statisticsexplained/index.php/Foreign_language_learning_statistics

Fremmedspråksenteret. (2018). Elevenes valg av fremmedspråk på ungdomsskolen 20172018. Retrieved from https://www.fremmedspraksenteret.no/neted/services/file/?hash=24419cb5212cb6e2b $\underline{\text { 58c62600ace8a0d }}$

Galindo Merino, M. d. M. (2016). La lengua materna en el aula de ELE Alicante, Biblioteca Virtual Miguel de Cervantes. Retrieved from http://www.cervantesvirtual.com/nd/ark:/59851/bmcrn564

Glaser, K. (2014). The Neglected Combination: A Case for Explicit-Inductive Instruction in Teaching Pragmatics in ESL. TESL Canada Journal, 30(7), 150. doi:10.18806/tesl.v30i7.1158 
Haight, C., Herron, C., \& Cole, S. P. (2007). The Effects of Deductive and Guided Inductive Instructional Approaches on the Learning of Grammar in the Elementary Foreign Language College Classroom. Foreign Language Annals, 40(2). doi:10.1111/j.19449720.2007.tb03202.x

Hansejordet, I. (2009). Grammatikken i spanskfaget: rapport frå ei kvalitativ undersøking. Retrieved from https://brage.bibsys.no/xmlui/bitstream/handle/11250/147934/FPS14 IH_nett $\% 5 b 1 \% 5 \mathrm{~d}$.pdf? sequence $=1 \&$ is Allowed $=\mathrm{y}$

Haukås, Å. (2014). Metakognisjon om språk og språklæring i et flerspråklighetsperspektiv. Acta Didactica Norge, 8(2), Art. 7, 16 sider.

Haukås, Å., Malmqvist, A., \& Valfridsson, I. (2016). Sprachbewusstheit und Fremdsprachenlernen: Inwiefern fördert die Grammatik in skandinavischen DaFLehrwerken die Sprachbewusstheit der Lernenden? Zeitschrift für Interkulturellen Fremdsprachenunterricht, 21(2), 13-26.

Heimark, G. E. (2013). Praktisk tilncerming i teori og praksis. Ungdomsskolelareres forståelse av en praktisk tilnarming i fremmedspråksundervisningen. Oslo.

Horwitz, E. K. (1990). Attending to the affective domain in the foreign language classroom. Paper presented at the Northeast Conference on the Teaching of Foreign Languages., Middlebury, VT.

Jessner, U. (1999). Metalinguistic Awareness in Multilinguals: Cognitive Aspects of Third Language Learning. Language Awareness, 8(3-4), 201-209. doi:10.1080/09658419908667129

Kern, R. G. (1995). Students' and teachers' beliefs about language learning. Foreign Language Annals, 28(1), 71-92.

Krashen, S. D. (1985). The input hypothesis: issues and implications. London: Longman.

Kvale, S., Brinkmann, S., Anderssen, T. M., \& Rygge, J. (2015). Det kvalitative forskningsintervju (3 ed.). Oslo: Gyldendal akademisk.

Labov, W. (1972). Sociolinguistic patterns: University of Pennsylvania Press.

Leow, R. P. (2007). Input in the L2 classroom: An attentional perspective on receptive practice. Practice in a Second Language: Perspectives from Applied Linguistics and Cognitive Psychology, 21.

Levine, G. S. (2003). Student and instructor beliefs and attitudes about target language use, first language use, and anxiety: Report of a questionnaire study. The Modern Language Journal, 87(3), 343-364.

Lindemann, B. (2008). Læring av fremmedspråk og motivasjon for språklæring etter innføringen av Kunnskapsløftet.

Llovet Vilà, X. (2016). Language teacher cognition and practice about a practical approach : the teaching of speaking in the Spanish as a foreign language classroom in Norwegian lower secondary school. University of Bergen, Bergen.

Modern Language Association. (2018). Enrollments in Languages Other Than English in United States Institutions of Higher Education, Summer 2016 and Fall 2016:

Preliminary Report. Retrieved from https://www.mla.org/content/download/83540/2197676/2016-Enrollments-ShortReport.pdf

Ní Dhiorbháin, A., \& Ó Duibhir, P. (2017). An Explicit-Inductive Approach to Grammar in Irish-Medium Immersion Schools. Language Awareness, 26(1), 3-24. doi:10.1080/09658416.2016.1261870 
Norris, J. M., \& Ortega, L. (2000). Effectiveness of L2 Instruction: A Research synthesis and quantitative meta-analysis. Language Learning, 50(3), 417-528. doi:10.1111/00238333.00136

Phipps, S., \& Borg, S. (2009). Exploring Tensions between Teachers' Grammar Teaching Beliefs and Practices. System: An International Journal of Educational Technology and Applied Linguistics, 37(3), 380-390. doi:10.1016/j.system.2009.03.002

Polio, C. G., \& Duff, P. (1994). Teacher's Language Use in University Foreign Language Classroom: A Qualitative Analysis of English and Target Language Alternation. Modern Language Journal, 78(3), 313-326. doi:10.2307/330110

Rothman, J., \& Guijarro-Fuentes, P. (2010). Input Quality Matters: Some Comments on Input Type and Age-Effects in Adult SLA. Applied Linguistics, 31(2), 301-306. doi:10.1093/applin/amq004

Russell, V. (2014). A Closer Look at the Output Hypothesis: The Effect of Pushed Output on Noticing and Inductive Learning of the Spanish Future Tense: FOREIGN LANGUAGE ANNALS. Foreign Language Annals, 47(1), 25-47. doi:10.1111/flan.12077

Schulz, R. A. (1996). Focus on form in the foreign language classroom: Students' and teachers' views on error correction and the role of grammar. Foreign Language Annals, 29(3), 343-364.

Shaffer, C. (1989). A Comparison of Inductive and Deductive Approaches to Teaching Foreign Languages. Modern Language Journal, 73(4), 395-403. doi:10.1111/j.15404781.1989.tb05319.x

Silverman, D. (2011). Interpreting Qualitative Data (4th ed.). London: Sage.

Simensen, A. M. (2007). Teaching a foreign language: principles and procedures (2nd. ed.). Bergen: Fagbokforlaget.

Solfjeld, K. (2007). Andre fremmedspråk på ungdomstrinnet-med praktisk tilnærming: rapport fra en intervjuunders $\varnothing$ kelse.

Spada, N., \& Tomita, Y. (2010). Interactions between type of instruction and type of language feature: A meta-analysis. Language Learning, 60(2), 263-308.

Spada, N. M. (1987). Relationships Between Instructional Differences and Learning Outcomes: A Process-Product Study of Communicative Language Teaching. Applied Linguistics, 8(2), 137-161. doi:10.1093/applin/8.2.137

Stoltz, J. (2011). L'alternance codique dans l'enseignement du FLE: Étude quantitative et qualitative de la production orale d'interlocuteurs suédophones en classe de lycée: Linnaeus University Press.

Swain, M. (2005). The output hypothesis: Theory and research. Handbook of research in second language teaching and learning, 1, 471-483.

Swain, M., \& Lapkin, S. (2000). Task-based second language learning: The uses of the first language. Language Teaching Research, 4(3), 251-274.

Tammenga-Helmantel, M., Arends, E., \& Canrinus, E. T. (2014). The Effectiveness of Deductive, Inductive, Implicit and Incidental Grammatical Instruction in Second Language Classrooms. System: An International Journal of Educational Technology and Applied Linguistics, 45(1), 198-210. doi:10.1016/j.system.2014.06.003

Tsagari, D., \& Diakou, C. (2015). Students' and teachers' attitudes towards the use of the first language in the EFL State School Classrooms. Research Papers in Language Teaching \& Learning, 6(1). 
Tsou, W. (2005). Improving Speaking Skills Through Instruction in Oral Classroom Participation. Foreign Language Annals, 38(1), 46-55. doi:doi:10.1111/j.19449720.2005.tb02452.x

Unsworth, S. (2008). Age and input in the acquisition of grammatical gender in Dutch. Second Lang. Res., 24(3), 365-395. doi:10.1177/0267658308090185

Ur, P. (2011). Grammar teaching. In E. Hinkel (Ed.), Handbook of research in second language teaching and learning (Vol. 2): Routledge.

Utdanningsdirektoratet. (2006). Foreign language subject curriculum. (FSP1-01). Retrieved from https://www.udir.no/k106/FSP1-01.

Utdanningsdirektoratet. (2015). Fremmedspråk - veiledning til laereplanen. Retrieved from https://www.udir.no/laring-og-trivsel/lareplanverket/veiledning-til-lp/fremmedsprak--veiledning-til-lareplanen/1-innledning/

Utdanningsdirektoratet. (2018a). Eksamensveiledning fremmedspråk nivå I, II og III. Retrieved from https://sokeresultat.udir.no/eksamensoppgaver.html\#?k=fremmedspr\%C3\%A5k\&start $=2$.

Utdanningsdirektoratet. (2018b). Karakterer i videregående skole. Retrieved from https://www.udir.no/tall-og-forskning/statistikk/statistikk-videregaendeskole/karakterer-vgs/.

Utdanningsforbundet. (2017). Nфkkeltall for videregående opplaring 2016. Retrieved from https://www.utdanningsforbundet.no/globalassets/varpolitikk/publikasjoner/faktaark/faktaark_2017.09.pdf

Vogel, S., Herron, C., Cole, S. P., \& York, H. (2011). Effectiveness of a Guided Inductive Versus a Deductive Approach on the Learning of Grammar in the Intermediate-Level College French Classroom. Foreign Language Annals, 44(2), 353-380. doi:10.1111/j.1944-9720.2011.01133.x

Vogel, S. P., \& Engelhard, G., Jr. (2011). Using Rasch Measurement Theory to Examine Two Instructional Approaches for Teaching and Learning of French Grammar. Journal of Educational Research, 104(4), 267-282. doi:10.1080/00220671003733815

Vold, E. T. (2017). Meaningful and contextualised grammar instruction: what can foreign language textbooks offer? The Language Learning Journal, 1-15. doi:10.1080/09571736.2017.1357745

Vold, E. T. (2018). L3 instruction and target language use. Paper presented at the Exploring Language Education (ELE): Global and Local Perspectives, Stockholm.

Wells, G. (1999). Using L1 to Master L2: A Response to Anton and DiCamilla's "SocioCognitive Functions of L1 Collaborative Interaction in the L2 Classroom". The Modern Language Journal, 83(2), 248-254.

Williams, J. N. (2009). Implicit Learning in Second Language Acquisition. In W. C. B. Ritchie, Tej K. (Ed.), The New Handbook of Second Language Acquisition: Emerald. 